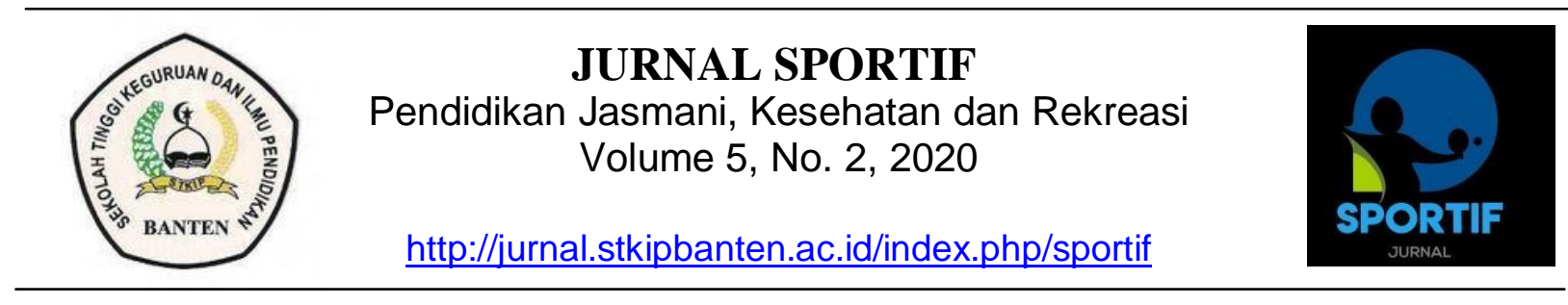

\title{
LATIHAN PASSING KE TEMBOK DALAM KEBERHASILAN PASSING FUTSAL
}

\author{
Gustaman Candra Pardini ${ }^{1}$, Saparudin ${ }^{2}$ \\ ${ }^{1}$ Sekolah Tinggi Keguruan dan Ilmu Pendidikan Banten \\ ${ }^{2}$ Mahasiswa, Pendidikan Jasmani, Kesehatan dan Rekreasi

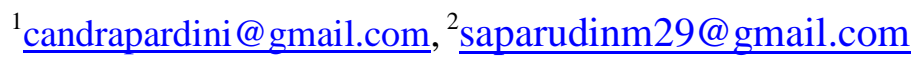

\begin{abstract}
ABSTRAK
Permasalahan yang ditemukan dalam penelitian ini yaitu: 1) Kurangnya power saat melakukan passing. 2) Perkenaan kaki pada bola yang kurang tepat sehingga akurasi passing kurang baik. 3) Kurangnya penguasaan pada bola. 4) Kurangnya latihan yang difokuskan pada passing. 5) Adanya keterbatasan sarana dan prasarana dalam permainan bola futsal seperti alat permainan bola futsal yang minim secara kuantitas dan kuranng secara kualitas. Penelitian ini bertujuan untuk mengetahui Pengaruh Latihan Passing Ke Tembok Terhadap Keberhasilan Passing Bola Futsal. Penelitian ini merupakan penelitian yang mengunakan Studi literatur. Teknik dalam pengumpulan data dalam penelitian ini menggunakan studi literatur yang dimana menggunakan data primer dan data sekunder. Teknik keabsahan data menggunakan triangulasi data. Hasil penelitian ini dapat disimpulkan bahwa terdapat pengaruh keberhasilan passing bola futsal sebelum dan sesudah pelaksanaan passing bola futsal dengan menggunakan metode latihan passing ke tembok. Dengan penggunaan metode latihan passing ke tembok berpengaruh secara signifikan terhadap keberhasilan passing bola futsal.
\end{abstract}

\section{Kata kunci : Passing Ke Tembok, Passing Bola Futsal}




\section{PENDAHULUAN}

Dalam kehidupan sehari-hari, kita sebagai manusia juga membutuhkan aktivitas olahraga untuk menjaga tubuh tetap sehat dan terhindar dari serangan penyakit. Olahraga juga bisa mebantu kita pada saat bekerja agar kita tidak merasakan kelelahan yang berlebihan, karena dengan olahraga kita bisa menjaga kebugaran tubuh agar selalu prima.

Olahraga adalah aktivitas jasmani yang berbentuk perlombaan atau pertandingan untuk memperoleh prestasi yang tinggi. Sedangkan menurut Wiarto menjelaskan bahwa "olahraga adalah kegiatan dalam perikehidupan manusia yang tidak hanya melibatkan aspek jasmani, tetapi juga aspek rohani dan aspek sosial". Di lingkungan sekitar terdapat pula banyak orang yang secara teratur memelihara kesehatannya. Ada berbagai macam jenis olahraga yang digemari siswa, salah satunya adalah olahraga futsal.

Futsal merupakan salah satu jenis olahraga yang sangat digemari oleh banyak orang dipenjuru dunia pada saat ini.. Permainan futsal dimainkan oleh lima orang dalam setiap timnya. Lapangan yang digunakannya pun lebih kecil dari pada sepak bola konvensional. Dengan ukuran yang lebih kecil dan dengan pemain yang lebih sedikit, permainan futsal lebih cenderung dinamis dan lebih membutuhkan kebugaran yang baik dari pemainnya. Pemain futsalharus mempelajari untuk bermain akurat dalam teknik dasar, seperti passing, control, dribbling, dan shooting.

Sedangkan menurut Murhananto dalam Brila Susi Hawindri Futsal adalah permainan sepak bola dalam ruangan yang dimainkan lima lawan lima pada ukuran lapangan yang lebih kecil. Dimana olahraga futsal itu sendiri membutuhkan intensitas sprint yang tinggi pada intensitas maksimal diselingi oleh periode pemulihan yang singkat

Diantara teknik dasar diatas, penulis akan membahas lebih mendalam mengenai passing, karena passing merupakan komponen yang sangat penting bagi permainan futsal. Bagian sisi dalam kaki lebih banyak digunakan pada saat bermain futsal, karena tingkat keakuratannya cukup baik saat akan melakukan passing atau umpan.

Passing merupakan salah satu teknik dalam permainan futsal yang digunakan untuk mengoper bola pada teman satu tim secara akurat dan cepat dengan menggunakan kaki bagian dalam, kaki bagian luar, tumit, dan ujung kaki.

Dalam melakukan passing masih ada siswa yang melakukan kesalahankesalahan mendasar pada saat melakukan teknik passing yaitu; 1) Kurangnya power saat melakukan passing. 2) Perkenaan kaki pada bola yang kurang tepat sehingga akurasi passing kurang baik. 3) Kurangnya penguasaan pada bola. 4) Kurangnya latihan yang difokuskan pada passing. 5) Adanya keterbatasan sarana dan prasarana dalam permainan bola futsal seperti alat permainan bola futsal yang minim secara kuantitas dan kuranng secara kualitas.

\section{METODE PENELITIAN}

Penelitian yang berkualitas tergantung pada penggunaan metode yang tepat. Dalam penelitian sangat memerlukan metode. Metode adalah langkah-langkah yang diambil untuk memudahkan penelitian. Metode yang digunakan dalam penelitian ini adalah studi literatur. Dalam melakukan penelitian ilmiah harus dilakukan teknik penyusunan yang sistematis untuk memudahkan langkah-langkah yang diambil. Begitu pula yang dilakukan penulis dalam penelitian ini, langkah pertama yaitu dengan melakukan studi literatur pada buku-buku, jurnal, dan penelitian yang telah dilakukan yang berkaitan dengan Passing Bola Futsal. 


\section{TEKNIK PENGUMPULAN DATA}

Teknik pengumpulan data yang digunakan dalam penelitian ini meliputi data dari literatur maupun referensi yang ada mengenai kendala-kendala yang sering terjadi pada latihan passing ke tembok terhadap keberhasilan passing bola futsal. Data yang digunakan sebagai berikut.

1. Data Primer

Data primer adalah data yang didapatkan secara langsung oleh peneliti dari subjek atau objek penelitian.

2. Data sekunder

Data sekunder adalah data yang didapatkan tidak secara langsung dari objek atau subjek penelitian, seperti buku-buku, artikel, jurnal, serta situs di internet.

\section{TEKNIK ANALISIS DATA}

Analisis data dilakukan untuk mengolah dan menginterprestasi data dengan tujuan memperoleh informasi yang sesuai untuk tujuan penelitian. teknik analisis data adalah proses sebuah proses penyederhanaan data kedalam bentuk yang lebih mudah dibaca dan interprestasikan. dalam menganalisis data, teknik analisis data yang digunakan dalam penelitian dengan model dari (Miles dan Huberman) yang terdiri dari tiga tahap, antara lain reduksi data, penyajian data dan penarikan kesimpulan/verifikasi yang dapat dilihat melalui gambar berikut :

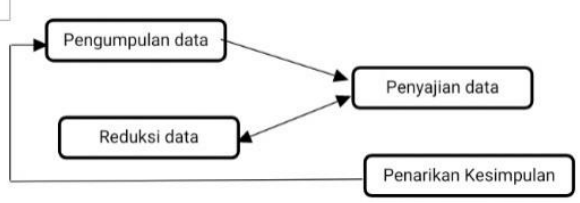

\section{Gambar 3. 2 Komponen-Komponen Analisis Data}

Langkah pertama, merangkum data adalah merangkum, memilih dan memfokuskan hal-hal pokok dan hal-hal yang dianggap penting, dengan upaya mencari tema dan polanya.

Langkah kedua, peneliti menyajikan (display) data yakni menyajikan data dalam penelitian kualitatif melalui sejumlah teks yang bersifat naratif.

Langkah ketiga, peneliti menarik kesimpulan dan verifikasi sebagai jawaban terhadap rumusan masalah yang telah dituangkan sejak awal. kesimpulan merupakan kegiatan yang dilakukan dengan tujuan mencari arti, makna, penjelasan yang dilakukan terhadap data yang telah dianalisis dengan mencari halhal penting. kesimpulan ini merupakan jawaban atas permasalahan yang ingin dikaji sebagaimana dijelaskan pada identifikasi dan perumusan masalah penelitian.

\section{HASIL PENELITIAN}

a) Berdasarkan data yang tercantum dalam sumber primer: Latihan Passing ke tembok sangatlah sesuai untuk dijadikan metode latihan untuk passing bola futsal, karena metode tersebut dilakukan saat melakukan latihan passing bola futsal secara berulang-ulang. Dalam pelaksanaannya latihan passing ke tembok juga lebih dipahami seorang siswa maupun atlet dalam pelaksanaan latihan passing, Karena latihan passing ke tembok dalam latihan yaitu dengan melatih peserta didik terhadap bahan yang sudah diajarkan/berikan agar memiliki keterampilan dari apa yang telah dipelajari bahwa dengan penggunaan metode latihan yang tepat akan berpengaruh terhadap keberhasilan atau pencapaian dari tujuan latihan itu sendiri, karena dengan latihan yang sesuai maka tingkat keberhasilan akan mudah dicapai oleh atlet maupun siswa.Oleh karena itu latihan passing ke tembok sangatlah tepat untuk meningkatkan keberhasilan 
passing bola futsal. Inti dari latihan passing ke tembok adalah untuk melatih siswa (atlet) dalam melaksanakan passing secara berulang-ulang untuk menanamkan kebiasaan-kebiasaan dalam melakukan passing bola futsal. Maka dari itu latihan passing ke tembok sangatlah baik untuk melatih keterampilan siswa maupun atlet. Teknik dalam bola futsal ditunjukan untuk memberikan pemahaman kepada siswa mengenai esensi dari teknik bola futsal khususnya latihan passing ke tembok.

b) Berikut merupakan pembahasan peneliti dari data sekunder :

Berdasarkan hasil penelitian dari berbagai sumber terutama sumber sekunder tentang latihan passing ke tembok terhadap keberhasilan passing bola futsal diantaranya: Pada penggunaan latihan passing ke tembok menyatakan bahwa terdapat berbagai hasil yang sangat signifikan dibandingkan dengan berbagai latihan lainnya dan pada penelitian ini instrumen yang digunakan adalah format penilaian keberhasilan passing pada permaianan bola futsal. Analisis statistik yang digunakan adalah analisis dengan menggunakan berbagai sumber yang relevan, dan dalam rekomendasi dari penelitian ini bahwa latihan passing ke tembok dapat dijadikan sebagai salah satu upaya dalam meningkatkan keberhasilan passing pada permaian bola futsal.

Dengan demikian dapat diketahui bahwa ada Pengaruh latihan passing ke tembok terhadap keberhasilan passing bola futsal. Kondisi tersebut dikarenakan keberhasilan passing bola futsal menggunakan latihan passing ke tembok memiliki berbagai keuntungan yaitu memudahkan pemahaman dalam perkenaan atau titik temu antara kaki dengan bola. Dalam hal ini atlet sudah mengukur dengan baik terhadap teknik passingnya, baik gerakan persiapan, pelaksanaan, maupun sikap akhir pada saat melakukan passing, mudah dalam konsentrasi dan dalam hal ini altet dapat berkonsentrasi penuh pada saat melakukan passing, agar peserta didik maupun atlet dapat melakukan passing dengan baik.

Dilihat dari hasil penelitian yang sebelumnya dengan berdasarkan hasil Penelitian tersebut menghasilkan keefektifan hasil perhitungan dengan menggunakan SPSS 16 dengan mean pretest $=6,3667$ dan mean post-test $=8,4000$, selisih hasil pre-test dan post-test atau selisih mean $=-2,03333$, t-hitung $=$ 15,503 , df $==29$ dan nilai-p $=0,00<0,05$. lalu ada yang signifikan perbedaan nilai antara nilai sebelumnya dan nilai setelah diberi perlakuan model pelatihan passing futsal berbasis permainan sisi kecil. Hasil ini menunjukkan bahwa model pelatihan passing futsal memiliki permainan sisi kecil yang efektif digunakan latihan passing futsal. Artinya terdapat pengaruh yang positif dan signifikan terhadap pengaruh latihan passing ke tembok terhadap keberhasilan passing bola futsal.

Menurut Dica Febri Wardana, dengan judul penelitian pengaruh latihan pendekatan taktik terhadap kemampuan passing dan dribbling pada peserta ekstrakurikuler futsal di SMA Negeri 1 Maospati hasil penelitiannya menunjukkan bahwa terdapat yang signifikan latihan pendekatan taktik terhadap keterampilan passing pada peserta ekstrakurikuler futsal di SMA Negeri 1 Maospati. Bahwasannya dilihat dari rerata pretest sebesar 6,35 dan rerata posttest sebesar 7,7 maka diperoleh angka Mean Difference sebesar 1,35, hal ini menunjukan perubahan yang lebih baik yaitu $21,25 \%$ dibandingkan sebelum diberikan latihan pendekatan taktik.

\section{PEMBAHASAN PENELITIAN}

Berdasarkan dari data yang telah dilakukan sebelumnya, didapatkan hasil 
dari beberapa sumber dan dapat disimpulkan bahwa latihan passing ke tembok terdapat pengaruh yang signifikian dan dapat dijadikan sebagai salah satu upaya dalam meningkatkan keberhasilan passing bola futsal oleh karena itu agar siswa terbiasa dan mampu dengan cepat menguasai segala permasalahan yang sedang dihadapi atau yang akan dihadapi oleh peserta didik.

Sebagaimana yang dikemukakan oleh Justinus Lhaksana bahwa, "Dilapangan yang rata dan ukuran lapangan yang kecil dibutuhkan passing yang keras dan akurat karena bola yang meluncur sejajar dengan tumit pemain. Ini disebabkan hampir sepanjang permainan futsal menggunakan passing. Untuk menguasai keterampilan passing, diperlukan penguasaan gerakan sehingga sasaran yang diinginkan tercapai" Dalam latihan passing ke tembok menekankan pada penguasaan bola untuk meningkatkan keterampilan siswa dalam melakukan passing sehingga dapat meningkatkan keberhasilan passing bola futsal.

Berdasarkan uraian di atas peneliti menyimpulkan bahwa latihan passing ke tembok merupakan latihan di mana siswa melakukan apa yang diperintahkan guru secara berulang-ulang. Peran guru dalam pembelajaran bola futsal adalah sebagai fasilitator untuk mendukung pembelajaran yang dilakukan oleh peserta didik. Pada penelitian ini latihan passing ke tembok yang diterapkan adalah latihan yang berulang-ulang selama 39 detik oleh karena itu dalam penelitian ini menjelaskan tahapan-tahapan atau fasefase dalam pelaksanaan melakukan passing. Dengan tujuan untuk menggunakan latihan passing ke tembok mengajak siswa untuk menanamkan kebiasan-kebiasan tertentu agar siswa mampu melatih kemampuan siswa dalam memecahkan masalah sehingga dapat meningkatkan keberhasilan passing bola futsal.
Dari uraian di atas dapat ditarik kesimpulan bahwa latihan passing ke tembok merupakan suatu cara mengajar dimana siswa melaksanakan kegiatankegiatan latihan, agar siswa memiliki keterampilan yang lebih tinggi dari apa yang dipelajari maka dari itu latihan passing ke tembok sangatlah cocok dan alangkah baiknya dijadikan acuan bagi para guru pendidikan penjaskes agar dapat meningkatkan keterampilan dalam melatih keberhasilan passing pada permaianan bola futsal maupun pemebelajaran penjaskes lainnya.

Oleh karena itu proses latihan passing ke tembok mempunyai kedudukan yang sangat penting dalam upaya pencapaian tujuan, karena latihan merupakan suatu cara atau jalan yang ditempuh yang sesuai, dan serasi untuk menyajikan suatu hal, sehingga akan tercapai suatu tujuan pembelajaran yang efektif dan efisien. Dengan latihan yang tepat salah satunya latihan passing ke tembok merupakan satu kegiatan melakukan hal yang sama, berulang-ulang secara sungguh-sungguh dengan tujuan untuk memperkuat suatu asosiasi atau menyempurnakan suatu keterampilan agar menjadi bersifat permanen.

Dengan demikian latihan passing ke tembok dapat digunakan untuk latihan dalam bola futsal, Seharusnya latihan harus sesuai dengan prinsip- prinsip latihan agar tujuan dapat tercapai. bahwa prinsip-prinsip latihan memiliki peranan penting terhadap aspek fisiologis dan psikologis olahragawan, dengan memahami prinsip-prinsip latihan akan mendukung upaya dalam meningkatkan kualitas latihan.

Keberhasilan penguasaan latihan passing dalam bola futsal diperoleh dari latihan yang benar, teratur serta didukung oleh program latihan yang tepat. Oleh karena itu, dengan modal berlatih tekun, disiplin, dan terarah di bawah bimbingan pelatih yang berkualitas, dapat menguasai berbagai teknik dasar bola futsal secara benar. 
Untuk menjadi pemain bola futsal yang baik dan berprestasi dituntut menguasai teknik dasar bola futsal. Teknik dasar yang dimaksud bukan hanya pada penguasaan teknik passing, tetapi juga melibatkan teknik- teknik yang berkaitan dengan permainan bola futsal.

\section{SIMPULAN}

Dengan demikian latihan passing ke tembok dapat digunakan untuk latihan dalam bola futsal, Seharusnya latihan harus sesuai dengan prinsip- prinsip latihan agar tujuan dapat tercapai. bahwa prinsip-prinsip latihan memiliki peranan penting terhadap aspek fisiologis dan psikologis olahragawan, dengan memahami prinsip-prinsip latihan akan mendukung upaya dalam meningkatkan kualitas latihan.

Keberhasilan penguasaan latihan passing dalam bola futsal diperoleh dari latihan yang benar, teratur serta didukung oleh program latihan yang tepat. Oleh karena itu, dengan modal berlatih tekun, disiplin, dan terarah di bawah bimbingan pelatih yang berkualitas, dapat menguasai berbagai teknik dasar bola futsal secara benar.

Maka dari itu dapat disimpulkan Terdapat pengaruh keberhasilan passing sebelum dan sesudah pelaksanaan passing bola futsal dengan menggunakan latihan passing ke tembok. Maka dapat disimpulkan bahwa latihan passing ke tembok berpengaruh secara signifikan terhadap keberhasilan passing bola futsal.

\section{DAFTAR PUSTAKA}

Setyawan Danny, Sapto Adi, Usman Wahyudi, (2018). Upaya Meningkatkan Keterampilan Teknik Passing Futsal Menggunakan Model Latihan Bervariasi Terhadap Tim Futsal Sma Negeri 2 Kota Probolinggo, Jurnal Sport Science, Vol. 8 No. 1, p-ISSN:1907-5111, eISSN:2620-4681
Hawindri Brila Susi, (2016). Pemanfaataan Panduan Latihan Teknik Dasar Futsal Bagi Atlet Pemula, Penjas dan Interdisipliner Ilmu Keolahragaan. hal. 3

Panyegar Gema Titah, (2014). Landasan Konseptual Perencanan dan Perancangan Gelanggang Futsal di Yogyakarta. hal. 14

Susanto Tori, (2020). Sejarah Futsal dan Perkembanganya di Dunia dan di Indonesia, Toriqa Media. https://toriqa.com/sejarah-futsal/

Dhewangga Wisnu, (2014). Pengaruh peningkatan intensitas latihan futsal terhadap vo2 max. hal 6

Wardana Dica Febri, (2015). Pengaruh Latihan Pendekatan Taktik Terhadap Kemampuan Passing Dan Dribbling Pada Peserta Ekstrakurikuler Futsal Di SMAN 1 Maospati., hal 16

Asbanu Riki, Kaswari, Andika Triansyah. (2018). Pengaruh Metode Bermain Terhadap Hasil Passing Bola Futsal Pada Ekstrakurikuler SMPN 3 Pontianak, Jurnal Program Studi Pendidikan Jasmani FKIP Untan Pontianak, Vol 7 No. 4, eISSN:2715-2723

Lubis Leonardo, Afan Maulana Muhammad, Oktavia Nandina. (2019). Role of Physical and Cognitive Factors in Passing Abilities of Futsal Athletes in Universitas Padjadjaran, Majlah Kedokteran Bandung, Vol 51 No. 2, p-ISSN:0126-074X, e-ISSN:23386223

Praniata Agus Rizqi, Bambang Kridasuwarso, Wahyuningtyas Puspitorini. (2019). Effectiveness of The Futsal Passing Exercise Model Based on Small-Sided Games for The Middle School Levels, Journal og Physical Education, Sport, Health and Recreation, Vol 8 No.1, https://doi.org/10.15294/active.v8i1. $\underline{27920}$ 